Pesq. Vet. Bras. 37(12):1505-1508, dezembro 2017 DOI: $10.1590 / \mathrm{S} 0100-736 \mathrm{X} 2017001200023$

\title{
Autochthonous case of Canine Visceral Leishmaniasis in a non-endemic area in Minas Gerais, Brazil ${ }^{1}$
}

\author{
Mariana Teixeira de Faria ${ }^{2}$, Fernando S. Barbosa ${ }^{3}$, Rafael G. Teixeira-Neto ${ }^{2}$, Guilherme \\ R.G. Pinheiro ${ }^{3}$, Marianna N. Manhani ${ }^{2}$, Andreza P. Marcelino ${ }^{4}$, José Ronaldo Barbosa ${ }^{4}$ \\ and Gilberto Fontes ${ }^{2 *}$
}

\begin{abstract}
Faria M.T., Barbosa F.S., Teixeira-Neto R.G., Pinheiro G.R.G., Manhani M.N., Marcelino A.P., Barbosa J.R. \& Fontes G. 2017. Autochthonous case of Canine Visceral Leishmaniasis in a non-endemic area in Minas Gerais, Brazil. Pesquisa Veterinária Brasileira 37(12):1505-1508. Campus Centro Oeste, Universidade Federal de São João del Rei, Rua Sebastião Gonçalves Coelho 400, Bairro Chanadour, Divinópolis, MG 35501-296, Brazil.E-mail: gilberto.fontes@pq.cnpq.br

Visceral Leishmaniasis by Leishmania infantum chagasi is an endemic zoonosis present in many areas of Brazil. This parasite needs reservoirs for maintenance of the infection and the presence of dogs in urban areas is a key factor for the spread of canine visceral leishmaniasis (CVL). The aim of this study was to report the first autochthonous case of CVL in the municipality of Iguatama, in west central region of Minas Gerais State. Dog infection by Leishmania infantum chagasi was confirmed in the municipality, previously considered as non-endemic area to CVL. The canine infection by Leishmania was confirmed by three immunological tests for antibodies: indirect immunofluorescence assay (IFA), rapid Dual Path Platform (DPP ${ }^{\circledR}$ ) CVL immunochromatographic test, enzyme-linked immunosorbent assay (ELISA), and microscopic demonstration of Leishmania amastigotes in imprints of spleen and bone marrow stained by Giemsa. The species Leishmania infantum chagasi was confirmed by molecular diagnosis (PCR). Studies are being carried out, aiming to describe the importance and the prevalence of this disease in the region and factors associated with its transmission.
\end{abstract}

INDEX TERMS: Leishmania infantum chagasi, canine visceral leishmaniasis, dogs, zoonosis.

RESUMO.- [Caso autóctone de Leishmaniose Visceral Canina em área indene em Minas Gerais.] Leishmaniose visceral causada por Leishmania infantum chagasi é uma zoonose endêmica em algumas regiões do Brasil. Este parasito necessita de reservatórios para a manutenção da infecção e a presença de cães em áreas urbanas é um fator importante para a manutenção e expansão da leishmaniose

\footnotetext{
${ }^{1}$ Received on November 15, 2016.

Accepted for publication on July 17, 2017

${ }^{2}$ Universidade Federal de São João del Rei (UFSJ), Campus Centro Oeste, Rua Sebastião Gonçalves Coelho, 400, Divinópolis, MG 35501-296, Brazil. *Corresponding author: gilberto.fontes@pq.cnpq.br

${ }^{3}$ Departamento de Parasitologia, Instituto de Ciências Biológicas, Universidade Federal de Minas Gerais (UFMG), Av. Antônio Carlos 6627, Cx. Postal 486, Belo Horizonte, MG 31270-901, Brazil.

${ }^{4}$ Serviço de Doenças Parasitárias, Divisão de Epidemiologia e Controle de Doenças, Fundação Ezequiel Dias (Funed), Rua Conde Pereira Carneiro 80, Gameleira, Belo Horizonte, MG 30510-010.
}

visceral canina (LVC). 0 objetivo deste estudo foi relatar o primeiro caso autóctone de LVC no município de Iguatama, na região Centro Oeste de Minas Gerais, cidade onde a LVC era tida como não existente. A infecção canina por Leishmania foi confirmada por três testes imunológicos para pesquisa de anticorpos: reação de imunofluorescência indireta (RIFI), teste rápido de imunocromatografia com plataforma dupla (DPP ${ }^{\circledR}$ LVC) e ensaio imunoenzimático (ELISA), e demonstração microscópica de amastigotas de Leishmania a partir de aposições de amostras de baço e de medula óssea corados pelo Giemsa. A espécie Leishmania infantum chagasi foi confirmada por diagnóstico molecular (PCR). Estudos estão sendo realizados com o objetivo de descrever a importância e a prevalência desta parasitose na região e os fatores associados com a transmissão.

TERMOS DE INDEXAÇÃO: Leishmania infantum chagasi, leishmaniose visceral canina, caninos, zoonose. 


\section{INTRODUCTION}

Human visceral leishmaniasis (HVL) is an endemic zoonosis in many areas of Brazil, caused by Leishmania (Leishmania) infantum (syn. Leishmania chagasi) (Mauricio et al. 2000). Recently, Marcili et al. (2014) by phylogenetic studies on trypanosomatid validates Leishmania infantum chagasi from Brazil differentiating it from L. infantum for the first time. HVL represents a problem of public health due to its high morbidity and wide geographic distribution (Brasil 2006). The dog has an essential role in the maintenance of this parasitosis and as a result of its proximity to the humans it is considered the main reservoir of the aethiologic agent of visceral leishmaniasis (VL) in urban areas (Gontijo \& Melo 2004, Teixeira-Neto et al. 2014). The canine infection has been pointed out as an essential factor in every registered outbreak of HVL, and no HVL cases are reported without the presence of infected dogs (Oliveira et al. 2008, Teixeira-Neto et al. 2014). The increasing of VL cases and disease's morbidity rates in the state of Minas Gerais, associated to the role of the dog in the biological cycle of the parasite, makes the study of canine visceral leishmaniasis (CVL) important to understand clearly the epidemiology of the disease (Gontijo \& Melo 2004, Dantas-Torres \& Brandão-Filho 2006, Oliveira et al. 2008, Teixeira-Neto et al. 2014).

The city of Iguatama, located on the west central region of the state of Minas Gerais it is not considered, up to the moment, an endemic area of the disease since there are no reports of HVL or CVL cases or epidemiological studies about leishmaniasis in the municipality. This paper describes the first autochthonous case of CVL reported in Iguatama.

\section{MATERIALS AND METHODS}

An about two-year-old mixed-breed male dog, born and raised indoors in Iguatama urban area, was found presenting suggestive signs of infection by Leishmania. Physical examination was carried out to evaluate the animal. However, clinical diagnosis of CVL is hard to be determined due to the great variability of clinical alterations that Leishmania-infected dogs may present including non-specific signs commonly observed in dogs with other diseases (Brasil 2006). Thus, the laboratorial diagnosis of canine leishmaniasis has been confirmed using serological exams to avoid clinical misdiagnosis.

Three tests were performed to confirm CVL by antibodies detection: Rapid immunochromatographic test based in dual path platform (DPP), the immunofluorescent-antibody test (IFA), and the enzyme-linked immunosorbent assay (ELISA), using the respective TR DPP ${ }^{\circledR}$ CVL, EIE-LVC and IFI-LVC serological kits, all of them produced by Instituto de Tecnologia em Imunobiológicos, Bio-Manguinhos, Fiocruz, Brazil) according to the instructions provided by the manufacturer. IFA was considered positive at serum dilution $>1: 40$.

DPP $^{\circledR}$ and ELISA are currently recommended by the Ministry of Health for CVL diagnosis. IFA was used until 2012 to confirm CVL diagnosis in ELISA positive dogs. Serodiagnosis were carried out at the Laboratório de Parasitologia da Universidade Federal de São João del Rei - Campus Centro-Oeste, in Divinópolis, Minas Gerais, accredited by the Ministry of Health of Brazil and Ezequiel Dias Foundation (FUNED) to carry out serological tests of CVL.

According to the Ministry of Health, it is recommended that dogs identified as seropositives by DPP ${ }^{\circledR}$ and ELISA as a confir- matory test must be euthanized, using the protocol regulated by the Federal Board of Veterinary Medicine (CFMV) (Brasil 2006).

Parasitological examinations were used to confirm infection by Leishmania. Imprinting of biological samples were collected, stained by Giemsa and examined under optical microscopy for identification the amastigotes forms of the parasite. Part of the same material was used to identify the Leishmania species involved in the dog's infection using DNA-based techniques. In the present study PCR-RFLP was used having as target HSP70 gene (1,300 bp), followed by digestion with HaeIII restriction enzyme for parasite identification.

\section{RESULTS}

The tested dog serum sample was positive for canine leishmaniasis (CL) by three methods, DPP ${ }^{\circledR}$, ELISA and IFA (serum dilution $=1: 80$ ).

The main clinical signs observed in the infected dog were: severe weight loss, dermatitis, alopecia, opaque bristles, keratoconjunctivitis, corneal opacity, blindness of one of the eyes, ulcerative lesions and paw edema (Fig.1A-C).

The dog was in debilitated conditions and as the three serological tests indicated Leishmania infection (CL), the owner authorized euthanasia of the animal for further parasitological confirmation.

After the euthanasia procedure imprints of the spleen, limph nodes and bone marrow revealed the presence of Leishmania amastigotes using optical microscopy (Fig.1D).

The spleen sample tested by PCR-RFLP presented a restriction enzyme pattern comparable to the reference strain of Leishmania infantum chagasi (MHOM/BR/74/PP75), proving the dog was infected with the causative agent of CVL (Fig.2).

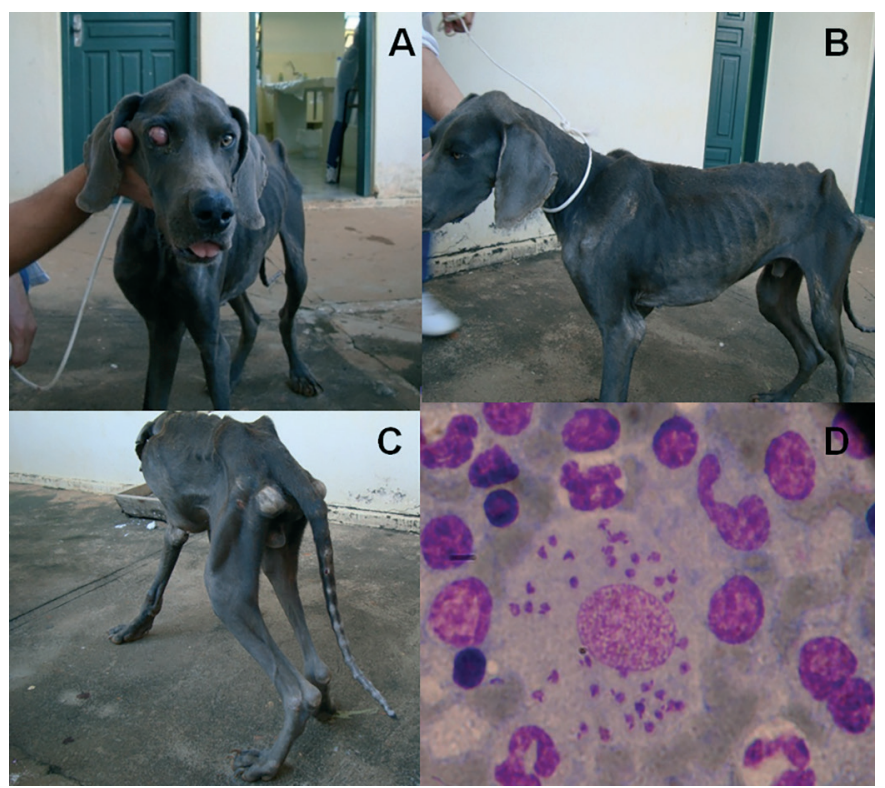

Fig.1. Clinical signs of the first dog associated with canine leishmaniasis in Iguatama municipality. (A) Corneal opacification. (B) Severe weight loss. (C) Legs edema and severe weight loss. (D) Leishmania amastigotes detected by optical microscopy in spleen imprint. Giemsa, obj.100. 


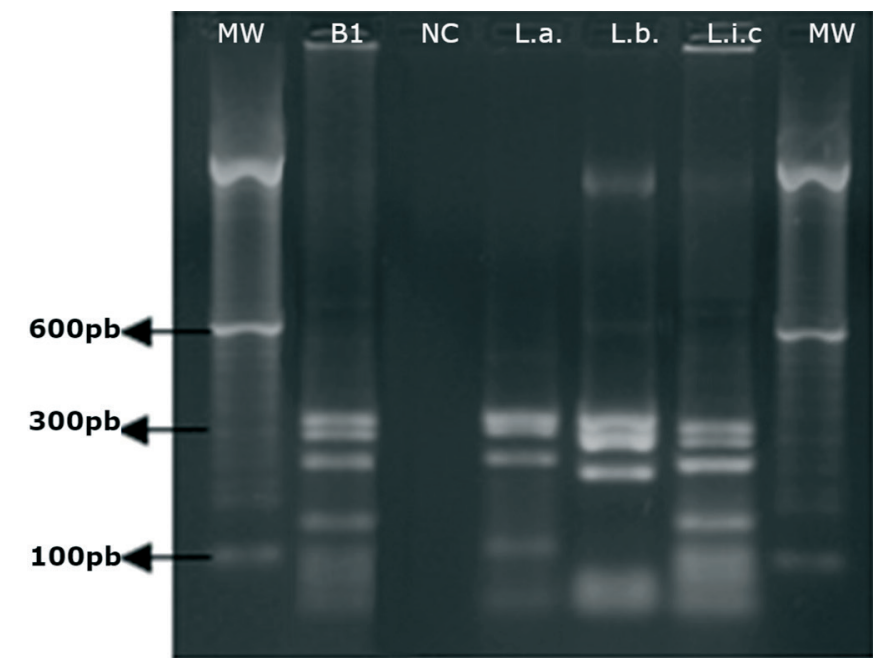

Fig.2. Polymerase chain reaction-restriction fragment length polymorphism using HaeIII digestion profile of heat shock protein $70 \mathrm{kDa}$ (Hsp70). MW = Molecular weight (100bp). B1 = Dog spleen sample. $\mathrm{NC}=$ Negative control. $\mathrm{La}=$ Positive control of Leishmania amazonensis. Lb = Positive control of L. braziliensis. Lic $=$ Positive control of $L$. infantum chagasi .

\section{DISCUSSION AND CONCLUSIONS}

This paper provides evidences about the risk of CVL in areas previously considered as non-endemic. Taking into account the correlation between the occurrence of disease in dogs and incidence of HVL, it is important to establish control measures to avoid the spread of the disease.

Due to variations in the sensitivity and specificity of the serological methods, it is important to perform confirmatory tests to establish CVL diagnosis in non-endemic areas. It has been demonstrated that the IFA results using promastigotes of Leishmania major-like antigens should be interpreted with caution in non-endemic areas for CVL (Schwanke et al. 2014).

Recently autochthonous cases of CVL were also reported in previously non-endemic areas like Maricá and Volta Redonda (Rio de Janeiro State) (Paula et al. 2009; Campos et al. 2013), and Florianópolis (Santa Catarina State) (Figueiredo et al. 2012). Report CVL cases in the country is extremely important, it shows that cities considered to be free of the disease are areas where the transmission could be occurring, although they are not identified on the epidemiological surveillance system (Paula et al. 2009, Figueiredo et al. 2012, Campos et al. 2013). These findings indicate that CVL is still in the process of spreading and urbanization in Brazil and emphasize the need of continuous epidemiological surveillance in regions of the country considered as disease-free areas. Trypanosoma and Leishmania infections affect wild and domestic animals and human populations. The growing process of deforestation and urbanization of forest areas in Brazil has given rise to introduction of humans and domestic animals to the sylvatic cycles of Trypanosoma and Leishmania species (Acosta et al., 2014).

Control measures of leishmaniasis require the application of a range of interventions because there are various biological factors that influence transmission depending on etiologic agents, hosts, and vectors (WHO 2013). Further investigations are being carried out to identify the vectors of the studied area considering sand fly identification and vector control is essential to prevent leishmaniasis spread. Other control measures to reduce or interrupt transmission of the disease are: migration control of dogs from endemic areas, mandatory serological diagnosis and reporting system for CVL, and educational measures targeting dog owners, veterinarians and civil society are important measures to prevent disease dissemination in Brazil (Figueiredo et al. 2012).

In addition to their proven roles as reservoirs of the aethiologic agent of visceral leishmaniasis (VL), dogs are also suspected by researchers to be reservoirs of cutaneous leishmaniasis. Therefore, when the first autochthonous case of CVL in a municipality is diagnosed through serological tests, identification of the parasite must be required in order to identify the Leishmania specie involved (Montalvo et al. 2010, Silva et al. 2010). Various techniques can be used to characterize the species responsible for the infection, such as molecular biology and immunohistochemical methods (Brasil 2006). PCR-RFLP method allows the discrimination of the majority of Leishmania species of significant medical and veterinary importance on the old and New World, including the main species found in Brazil: Leishmania infantum, L. amazonensis, L. braziliensis, $L$. guyanensis (Quaresma et al. 2009).

In a study carried out on domestic dogs of Belo Horizonte PCR was used to detect Leishmania in biological material from naturally infected dogs (Quaresma et al. 2009). In this study, the PCR positive samples were further submitted to RFLP and two species were found parasitizing the dogs, $L$. infantum and L. braziliensis, being the last uncommon in the region (Quaresma et al. 2009). Thus, identifying the species causing CVL is essential to epidemiological understanding of the disease.

The main challenges for the VL surveillance on the country are related to the lack of available resources, especially in country towns, and also the absence of epidemiological research of the distribution of VL.

Studies to determine the distribution of CVL, especially in regions with no previous reports, are extremely important to identify new areas of transmission of the parasite (Teixeira-Neto et al. 2014). Thus, controls measures can be taken in order to break the chain of and avoid the spread of VL.

The results of this study confirm the first case of a dog naturally infected with Leishmania infantum chagasi in the municipality of Iguatama, on the west central region of the state of Minas Gerais. Further studies are necessary to evaluate the epidemiological situation in the area, in order to stop the expansion of the canine disease and consequently the emergence of human cases.

Acknowledgments.- To Flavia Mauricio da Rocha Fontes for English translation and Prof. Eliana Maria Mauricio da Rocha for the revision of the manuscript.

Conflict of interest statement.- The authors have no competing interests. 


\section{REFERENCES}

Acosta I.C.L., Costa A.P., Gennari S.M. \& Marcili A. 2014. Survey of Trypanosoma and Leishmania in wild and domestic animals in an Atlantic rainforest fragment and surroundings in the state of Espírito Santo, Brazil. J. Med. Entomol. 51(3):686-693.

Brasil 2006. Manual de Vigilância e Controle da Leishmaniose Visceral. Ministério da Saúde, Brasília, DF. 122p.

Campos M.P., Silva D.A., Madeira M.F., Júnior A.A.M.V. \& Figueiredo F.B. 2013. First autochthonous case of canine visceral leishmaniasis in Volta Redonda, Rio de Janeiro, Brazil. Revta Bras. Parasitol. Vet. 22(3):424-426.

Dantas-Torres F. \& Brandão-Filho S.P. 2006. Visceral Leishmaniasis in Brazil: revisiting paradigms of epidemiology and control. Revta Inst. Med. Trop. São Paulo 48(3):151-156.

Figueiredo F.B., Lima F.E.F., Tomio J.E., Indá F.M.C., Corrêa G.L.B. \& Madeira M.F. 2012. Leishmaniose Visceral Canina: Dois casos autóctones no município de Florianópolis, estado de Santa Catarina. Acta Scient. Vet. 40(1):1026.

Mauricio I.L., Stothard J.R. \& Miles M.A. 2000. The strange case of Leishmania chagasi. Parasitol. Today 16(5):188-189.

Gontijo C.M.F. \& Melo M.N. 2004. Leishmaniose visceral no Brasil: quadro atual, desafios e perspectivas. Revta Bras. Epidemiol. 7(3):338-349.

Marcili A., Sperança M.A., Costa A.P., Madeira M.F., Soares H.S., Sanches C.O.C.C., Acosta I.C.L., Girotto A., Minervino A.H.H., Horta M.C., Shaw J.J. \& Gennari S.M. 2014. Phylogenetic relationships of Leishmania species based on trypanosomatid barcode (SSU rDNA) and gGAPDH genes: Taxonomic revision of Leishmania (L.) infantum chagasi in South America. Infect. Genet. Evol. 25(1):44-51.

Montalvo A.M., Fraga J., Monzote L., Montano I., De Doncker S., Dujardin J.C.
\& Van der Auwera G. 2010. Heat-shock protein 70 PCR-RFLP: a universal simple tool for Leishmania species discrimination in the New and Old World. Parasitology 137(8):1159-1168.

Oliveira C.L., Morais M.H.F. \& Machado-Coelho G.L.L. 2008. Visceral leishmaniasis in large Brazilian cities: Challenges for control. Cad. Saúde Públ. 24(12):2953-2958.

Paula C.C., Figueiredo F.B., Menezes R.C., Mouta-Confort E., Bogio A. \& Madeira M.F. 2009. Leishmaniose visceral canina em Maricá, Estado do Rio de Janeiro: relato do primeiro caso autóctone. Revta Soc. Bras. Med. Trop. 42(1):77-78.

Quaresma P.F., Murta S.M.F., Ferreira E.C., Da Rocha-Lima A.C.V.M., Xavier A.A.P. \& Gontijo C.M.F. 2009. Molecular diagnosis of canine visceral leishmaniasis: identification of Leishmania species by PCR-RFLP and quantification of parasite DNA by real-time PCR. Acta Trop. 111(3):289-294.

Schwanke K., Silva A.M.M., Pacheco A., Bahia M., Silveira F.T., Scofield A. \& Góes-Cavalcante G. 2014. Molecular diagnosis and frequency of anti-Leishmania infantum chagasi antibodies in dogs in Belém/Pará, Brazil. Pesq. Vet. Bras. 34(3):255-260.

Silva L.A., Souza C.S., Graça G.C., Porrozzi R. \& Cupolillo E. 2010. Sequence analysis and PCR-RFLP profiling of the hsp70 gene as a valuable tool for identifying Leishmania species associated with human leishmaniasis in Brazil. Infect. Genet. Evol. 10(1):77-83.

Teixeira-Neto R.G., Silva E.S., Nascimento R.A., Belo V.S., Oliveira C.L., Pinheiro L.C. \& Gontijo C.M.F. 2014. Canine visceral leishmaniasis in an urban setting of Southeastern Brazil: an ecological study involving spatial analysis. Parasit. Vectors 7:485.

WHO - World Health Organization. Leishmaniasis, Fact sheet № 375 February 2013. Available in: <http://www.who.int/mediacentre/factsheets/fs375/en/index.html> Access on Nov. 18, 2013. 